\title{
Genotype-environment interaction for production characteristics in cherry tomato (Solanum spp.)
}

\section{Interacción genotipo-ambiente de caracteres de producción en tomate tipo cereza (Solanum spp.)}
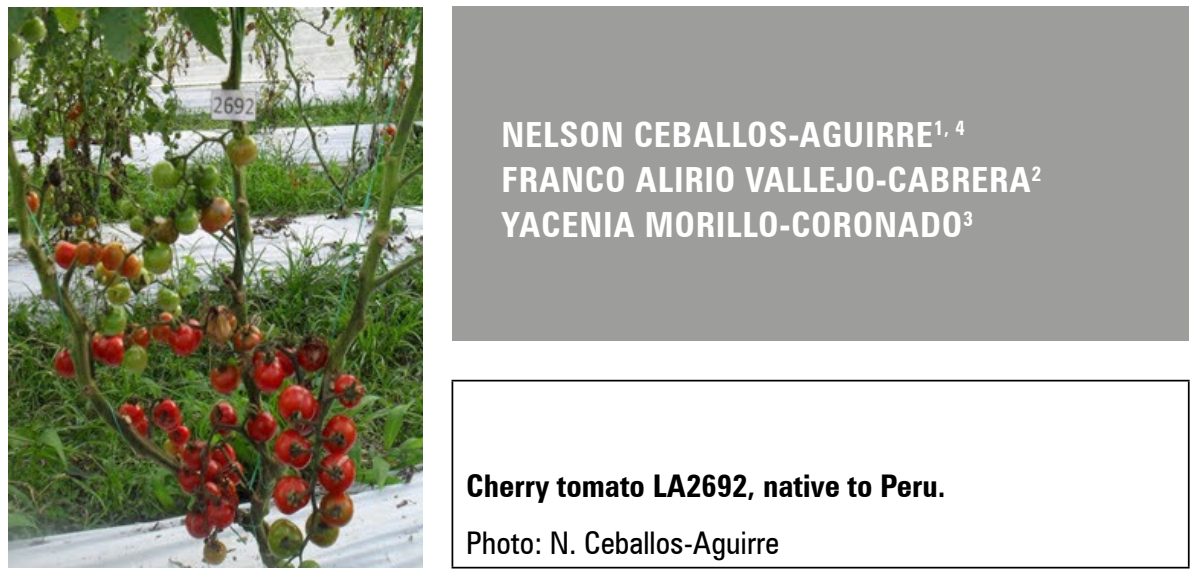

\begin{abstract}
Much of the tomato diversity is found in cherry-type populations. There are promising wild cherry tomato species with good behavior in terms of yield and quality that can be produced with a minimum of agroinputs. The genetic expression of genotypes is influenced by the optimal environment they can develop in. The genotype-environment interaction must be known to estimate the phenotypic adaptability in different environments. The objective of this research was to evaluate the genotype-environment interaction for 10 cherry tomato introductions in nine environments, four of which were artificial environments $(0,60,120$ and $180 \mathrm{~kg} \mathrm{ha}^{-1}$ of potassium) established in natural environments on the Farms Montelindo, Tesorito and CEUNP. The experiment design used randomized complete blocks with four replicates; the experiment unit consisted of five effective plants per introduction. The evaluated variables were production per plant (PFT) $(\mathrm{kg} / \mathrm{pl})$, number of fruits per plant (NFT), and average fruit weight (AWF) (g/fruit). The genotype Xenvironment interaction and the stability of the 10 genotypes were estimated with the AMMI multivariate model. The environments for T120K and T180K were optimal for the variables associated with production (PFT, NFT and AWF), with IAC1621, IAC426 and IAC1624 being the most promising genotypes per environment on the Farms Tesorito, Montelindo and CEUNP, respectively. The results are useful for the identification of genotypes in key locations for selection and evaluation in breeding programs.
\end{abstract}

\footnotetext{
Additional keywords: AMMI; adaptability; stability; wild tomato; yield; potassium

Universidad de Caldas, Facultad de Ciencias Agropecuarias, Manizales (Colombia). ORCID: Ceballos-Aguirre, N.: 0000-0002-8463-3379

2 Universidad Nacional de Colombia, Sede Palmira, Palmira (Colombia). ORCID: Vallejo-Cabrera, F.A.: 0000-0002-2739-0745

3 Corporación Colombiana de Investigación Agropecuaria (Agrosavia), Palmira, Colombia. ORCID Morillo-Coronado, Y.: 0000-0003-1974-3464

4 Corresponding author.nelson.ceballos@ucaldas.edu.co
} 


\section{RESUMEN}

Gran parte de la diversidad del tomate se encuentra en las poblaciones tipo cereza. Se considera que hay especies silvestres de tomate cereza promisorias con buen comportamiento en rendimiento y calidad que pueden ser producidos con un mínimo de agroinsumos. La expresión genética de los genotipos está influenciada por el ambiente óptimo, en el cual puedan desarrollarse, para ello es necesario conocer la interacción genotipo-ambiente que permita estimar la adaptabilidad fenotípica de estos en diferentes ambientes. El objetivo de esta investigación fue evaluar la interacción genotipo-ambiente de 10 introducciones de tomate cereza en nueve ambientes, de los cuales cuatro fueron ambientes artificiales $\left(0,60,120\right.$ y $180 \mathrm{~kg} \mathrm{ha}^{-1}$ de potasio) establecidos en ambientes naturales de las Granjas Montelindo, Tesorito y CEUNP. El diseño experimental fue bloques completos al azar, con cuatro repeticiones, la unidad experimental fue de cinco plantas efectivas por introducción. Las variables evaluadas fueron: producción por planta (PFT) $(\mathrm{kg} / \mathrm{pl})$, número de frutos por planta (NFT) y peso promedio de fruto (PPF) (g/fruto). Se estimó la interacción genotipo-ambiente y la estabilidad de los 10 genotipos a través del modelo multivariado AMMI. Los ambientes de T120K y T180K fueron óptimos para las variables asociadas a producción (PFT, NFT y PPF), siendo los genotipos más promisorios por ambiente IAC1621, IAC426 y IAC1624, en las Granjas Tesorito, Montelindo y CEUNP; respectivamente. Los resultados son útiles para la identificación de genotipos en localidades claves de selección y evaluación en programas de mejoramiento.

Palabras clave adicionales: AMMI; adaptabilidad; estabilidad; tomate silvestre; rendimiento; potasio.

Received: 21-03- 2021 Accepted: 26-04-21 Published: 05-05-2021

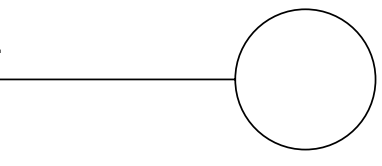

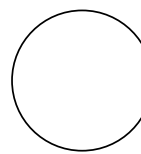

The tomato historically went from being a merely ornamental plant to being one of the most important vegetables today in terms of consumption and production (Abdallah et al., 2016; Srinivas et al., 2019). In Colombia, production in 2019 was 556,692 $\mathrm{t}$ with a yield of $65,66 \mathrm{t} \mathrm{ha}^{-1}$ using a total area of 8,478 ha (Agronet, 2021; FAO, 2021). Currently, three genetic groups have been described: the wild ancestor $S$. pimpinellifolium, the transitional form $S$. lycopersicum var. cerasiforme, and the cultivated species $S$. lycopersicum var. lycopersicum (Casals et al., 2018).

The cherry tomato corresponds to the species Solanum lycopersicum var. cerasiforme, a botanical variety that is considered an ancestral form of cultivated tomatoes and that is found in the tropical and subtropical regions of the world. It is also known as cherry, pajarito or vagabundo (Medina and Lobo, 2001). All wild species related to tomatoes are native to the Andean region of Chile, Bolivia, Peru, Ecuador, and Colombia, including the Galapagos Islands. Wild species have broad adaptation to different environments because they grow at different altitudes, in narrow mountains geographically isolated from each other, and also adapt to specific microclimatic soil conditions (Flores- Hernández et al., 2017).

\section{INTRODUCTION}

Nowadays, the cherry tomato has positioned itself gastronomically, not only as garnish but as an integral part of salads, sauces and cocktails (Machado et al., 2003). Colombia does not have production records because few areas cultivate this fruit. In other countries, some records report yields between 41 and $42 \mathrm{t} \mathrm{ha}^{-1}$ under semi-controlled conditions (Herrera, 2015).

The genotypexenvironment interaction (GEI) refers to the differential response of genotypes evaluated under different environmental conditions (Tonk et al., 2011) and involves environmental conditions (agroecological, climatic and agronomic) and all physiological and genetic factors that determine plant growth and development (Mohammadi et al., 2016; Wardofa et al., 2019). GEI is of great concern to plant breeders because a high interaction can reduce selection gains and make it difficult to identify superior cultivars. Measuring GEI is important to determining the optimal strategy to select genotypes adapted to specific environments (Nowosad et al., 2016).

Several methods have been used to evaluate the response of genotypes through the environment 
and the GxE interaction in agricultural experiments. Eberhart and Russell (1966) proposed a joint regression analysis to estimate the average performance of one genotype in different environments relative to the average performance of all genotypes in the same environment. The Principal Additive Effects and Multiplicative Interactions Model (AMMI) is the most widely used method because it considers genotypes and environments as additive and linear effects, facilitating studies using an analysis of variance (ANAVA), while GEI has multiplicative effects that can be analyzed with a Principal Component Analysis (Crossa et al., 1990).

The genotype-environment interaction and the phenotypic stability of tomatoes have been studied by several researchers, including Mandal et al. (2000), Panthee et al. (2012), Mohamed et al. (2013), Al-Aysh (2014), Zakher et al. (2016), and Shankar et al. (2017), among others.

The objective of this study was to evaluate the genotype-environment interaction of production characteristics in cherry tomatoes by applying the AMMI model to elucidate how genotypes respond to diverse natural and artificial environments for cherry tomatoes.

\section{MATERIALS AND METHODS}

\section{Genetic material}

Nine cherry tomato genotypes were evaluated from the Germplasm bank of the Universidad de Caldas, along with a commercial control called 'Sweet Million' (Tab. 1).

Table 1. Cherry tomato introductions used this study on the genotype-environment interaction.

\begin{tabular}{|l|c|c|}
\hline Genotype & Species & Origin \\
\hline IAC1621 & T. cereja Alemán 12 & Brazil \\
\hline IAC1624 & T. cereja & Brazil \\
\hline IAC1688 & T."Lili"cereja & Brazil \\
\hline IAC391 & T. red cherry & Brazil \\
\hline IAC412 & Cherry tomato & Brazil \\
\hline IAC426 & T. cherry Juliet & Brazil \\
\hline IAC445 & T. cereja Jundiai & Brazil \\
\hline LA2076 & Tomate cereza & California \\
\hline LA2692 & Cherry tomato & Peru \\
\hline Sweet Million & Solanum lycopersicum var. cerasiforme & Control \\
\hline
\end{tabular}

*IAC: Introductions from the Agronomic Institute of Campinas, Campinas, Brazil.

**A: Introductions from the Tomato Genetics Resources Center (TGRC), University of California-Davis.

Table 2. General characteristics and soil nutrient levels at the test sites for estimating GxE interactions in cherry tomatoes.

\begin{tabular}{|c|c|c|c|}
\hline ID Farm & Montelindo farm & Centro Experimental CEUNP) & Tesorito farm \\
\hline Location & Municipality of Palestina (Caldas) & Municipality of Candelaria (Valle del Cauca) & Manizales (Caldas) \\
\hline Geographic coordinates & $5^{\circ} 04^{\prime} \mathrm{N}, 75^{\circ} 45^{\prime} \mathrm{W}$ & $3^{\circ} 24^{\prime} \mathrm{N}, 76^{\circ} 26^{\prime} \mathrm{W}$ & $\begin{array}{c}5^{\circ} 01^{\prime} 47^{\prime \prime} \mathrm{N} \\
75^{\circ} 26^{\prime} 03^{\prime \prime} \mathrm{W}\end{array}$ \\
\hline Elevation (m) & 1,030 & 980 & 2,340 \\
\hline Mean precipitation (mm) & 2,200 & 1,009 & 2,000 \\
\hline Average temperature $\left({ }^{\circ} \mathrm{C}\right)$ & 23 & 24 & 17.5 \\
\hline $\mathrm{pH}$ & 4.7 & 6.54 & 5.2 \\
\hline Nitrogen (\%) & 0.54 & 0.1 & 0.41 \\
\hline Organic mat. $(\%)$ & 14.64 & 2.07 & 10.18 \\
\hline Phosphorus $\left(\mathrm{mg} \mathrm{kg}^{-1}\right)$ & 21 & 227 & 125 \\
\hline Potassium $\left(\mathrm{cmol} \mathrm{kg}^{-1}\right)$ & 0.29 & 0.66 & 0.97 \\
\hline Calcium $\left(\mathrm{cmol} \mathrm{kg}^{-1}\right)$ & 0.82 & 13 & 4.74 \\
\hline Magnesium $\left(\mathrm{cmol} \mathrm{kg}^{-1}\right)$ & 0.19 & 5.84 & 1.27 \\
\hline Iron $\left(\mathrm{mg} \mathrm{kg}^{-1}\right)$ & 189 & 61.5 & 276 \\
\hline Manganese $\left(\mathrm{mg} \mathrm{kg}^{-1}\right)$ & 13.43 & 69.8 & 10.44 \\
\hline Zinc $\left(\mathrm{mg} \mathrm{kg}^{-1}\right)$ & 9.52 & 5.35 & 8.33 \\
\hline Copper $\left(\mathrm{mg} \mathrm{kg}^{-1}\right)$ & 6.52 & 4.71 & 5.33 \\
\hline Sulfur $\left(\mathrm{mg} \mathrm{kg}^{-1}\right)$ & 31.8 & 22.8 & 77.86 \\
\hline Boron $\left(\mathrm{mg} \mathrm{kg}^{-1}\right)$ & 0.1 & 0.53 & 1.1 \\
\hline
\end{tabular}




\section{Location}

The trials were established in three natural environments: Montelindo and Tesorito farms belonging to the Universidad de Caldas, and the Experimental Center of the Universidad Nacional de Colombia, Palmira (CEUNP). Table 2 shows the general characteristics of each evaluation environment.

The introductions were planted in trays with 72 locules with peat-type substrate grade 3 . The transplant was done $30 \mathrm{~d}$ later when the seedlings had four true leaves (Jaramillo et al., 2007).

\section{Evaluated variables}

The most important production characteristics for cherry tomatoes were evaluated, such as number of fruits per plant (NFT), average weight of the fruit (g) (AWF) and production/plant ( $\mathrm{kg} / \mathrm{pl})(\mathrm{PFT})$.

\section{Experiment design}

The experiment design used randomized complete blocks with four blocks that used the blocking criterion potassium fertilization level $(0,60,120,180 \mathrm{~kg}$ $\left.\mathrm{ha}^{-1}\right)$, with the level $0 \mathrm{~kg} \mathrm{ha}^{-1}$ reported for the soil.

On the Tesorito farm, the levels 0,60,120,180 $\mathrm{kg} \mathrm{ha}^{-1}$ of potassium were denominated environments T0K, T60K, T120K and T180K, respectively; likewise, on the Montelindo farm, conserving the same levels of potassium, the environments were named M0K, M60K, M120K and M180K, respectively; in addition, the Palmira environment was called PAL.

The effective size of the experiment unit was seven plants, of which the five central plants were used as the useful plot, planted at $1.5 \mathrm{~m}$ between rows, 0.50 $\mathrm{m}$ between plants, and $2 \mathrm{~m}$ between blocks. The agronomic management was the commercial plan for tomato crops, defined by Jaramillo et al. (2007). Once the fruits reached full maturity ( $65 \mathrm{~d}$ after transplanting for the Montelindo and CEUNP farms and $95 \mathrm{~d}$ for the Tesorito farm), they were harvested in accordance with each introduction until the plants completed 10 harvest passes (1 pass/week).

\section{Analysis of the information}

An analysis of variance was performed using the SAS GLM procedure (SAS Institute), under the statistical models (Steel and Torrie, 1997):
Individual statistical model:

$Y_{i j}=\mu+B_{j}+G i+(B G)_{i j}+\varepsilon_{i j}$

where, $Y_{i j}$ is observed value of the $i^{\text {th }}$ genotype in the $j^{\text {th }}$ block; $\mu$ is general mean; $B_{j}$ is effect of block $j$ (the block being the level of potassium fertilization 0,60 , $\left.120,180 \mathrm{~kg} \mathrm{ha}^{-1}\right) ; G_{i}$ is effect of genotype $i ;(B G)_{i j}$ is effect of the interaction of genotype $i$ in block $j$, and $\varepsilon_{i j}$ is experiment error.

The difference in each of them was established by comparing means with the average partition test or Duncan's test $(P \leq 0.05)$.

Combined statistical model:

$Y_{i j k}=\mu+A_{k}+\left(B_{j}\right)_{k}+G_{i}+(G A)_{i k}+\varepsilon_{i j k}$

where, $Y_{i j k}$ is mean behavior of genotype $i$ in replicate $j$ in environment $k ; \mu$ is general mean of the experiment for the nine environments; $A_{k}$ is effect of environment $k ;\left(B_{j}\right)_{k}$ is effect of replicate $j$ within locality $k ; G_{i}$ is effect of genotype $i,(G A)_{i k}$ is effect of the interaction of genotype $i$ in environment $k$, and $\varepsilon_{i j k}$ is combined experiment error.

\section{AMMI analysis}

The AMMI multivariate analysis was represented by the equation proposed by Crossa (1990):

$Y_{i j}=\mu+g_{i}+e_{j}+\sum_{k=1}^{p}+\lambda_{k} \gamma_{i k} \alpha_{j k}+\varepsilon_{i j}$

where, $Y_{i j}$ is value observed in the $i$-th genotype in the $j$-th environment; $\mu$ is overall mean; $g_{i}$ is mean of the $i$-th genotype minus the overall mean; $e_{j}$ is mean of the $j$-th environment minus the overall mean; $\lambda_{k}$ is square root of the characteristic value of the $k$-th axis of the principal component analysis (PCA)k; $\alpha_{j k} \gamma i k$ is qualifications of the PCA for the $k$-th axis of the $i$-th genotype and $j$-th environment; and $\varepsilon_{i j}$ is residual of the model. Finally, the analysis and figures (biplots) were generated using InfoGen (Balzarini and Di Rienzo, 2003).

\section{RESULTS AND DISCUSSION}

\section{Combined analysis of variance}

The combined analysis of variance indicated that there were significant differences in the environments 
for variables NFT, AWF and PFT, indicating that the tomato genotypes behaved differently in the three evaluation environments (Tab. 3). Similar results were reported by Sánchez et al. (2015), who found significant differences in the environments for variables days to first cut, average weight of the fruit and yield, when evaluating 25 tomato genotypes in three environments using the AMMI model. Likewise, these results are in accordance with those found by Al-Aysh (2014) and Hernández-Leal et al. (2019). The mean squares were highly significant $(P \leq 0.01)$ for all characteristics, suggesting that environmental effects play an important role in the expression of phenotypic value in the evaluated genotypes.

Highly significant differences were found among the genotypes for the three variables. A variable response of tomato genotypes to different environments in the case of yield per plant was also observed by Prasanna et al. (2007). Likewise, the mean squares of the GEI were highly significant $(P \leq 0.01)$ for NFT, PPF and PFT; therefore, the tomato genotypes interacted considerably in the three evaluation environments.

Savale and Patel (2017) studied the stability of 45 tomato genotypes (32 hybrids, 12 parents and one commercial control) under three different environments to identify the most stable genotypes. The pooled analysis of variances indicated that the $G \times E$ interactions were highly significant for fruit yield per plant $(\mathrm{kg})$ and pericarp thickness $(\mathrm{mm})$. The linear and non-linear components of the $\mathrm{G} \times \mathrm{E}$ interactions were significant for these characteristics, indicating that the response of genotypes varies in different environments.

Al-Aysh (2014) evaluated 14 local tomato varieties (Solanum lycopersicum L.) to estimate the magnitude of the interaction genotype-environment and phenotypic stability for the number of branches per plant, number of fruits per plant, average weight of fruit (g), and fruit yield per plant $(\mathrm{kg})$ using the methodology of Eberhart and Russell (1966). Because of the genotypes, environments (years) and genotypeenvironment interaction, the mean squares were highly significant $(P \leq 0.01)$ for most of the evaluated characteristics. The components of the genotypeenvironment interaction (linear), together with the combined deviation, were significant for the number of fruits per plant, suggesting the importance of both the linear and non-linear components in the construction of the GxE interaction.

The yield $(\mathrm{kg} / \mathrm{pl})$ of the 10 tomato genotypes in the nine environments determined that $31.35 \%$ of the sum of total squares was attributable to genotypic effects, while the environmental effects and the $\mathrm{G} \times \mathrm{E}$ interaction represented 39.73 and $28.92 \%$, respectively. Significant differences were found $(P \leq 0.01)$ in all sources of variation with a mean yield of $1.02 \mathrm{~kg} /$ $\mathrm{pl}$ (Tab. 3). For the production variables, 57.36 and $45.47 \%$ of the total sum of squares was due to environmental effects for NFT and AWF, respectively, while the genotypic effects represented 21.5 and $30.26 \%$ of the total sum of squares for the same variables. The effects of the $\mathrm{G} \times \mathrm{E}$ interaction showed the lowest values of the total sum of squares, 21.15 and $24.27 \%$, respectively. The average reached in the NFT was 125.18, while the AWF showed an average weight of $11.82 \mathrm{~g}$ (Tab. 3).

\section{Analysis of the interaction genotype-environment by the AMMI model}

The principal components analysis indicated that the first two principal components (PC1 and PC2) were significant $(P \leq 0.01)$ and, together, explained 85,88 and $87 \%$ of the existing variation in the sum of squares for the interaction of variables PFT, NFT

Table 3. Combined variance analysis for production variables in ten cherry tomato genotypes in nine environments.

\begin{tabular}{|c|c|c|c|c|c|c|c|c|c|c|}
\hline \multirow{2}{*}{ Source of variance } & \multirow{2}{*}{ D.f } & \multicolumn{3}{|c|}{ Yield (kg/pl) } & \multicolumn{3}{|c|}{ Number of fruits per plant } & \multicolumn{3}{|c|}{ Average weight of the fruit $(\mathrm{g})$} \\
\hline & & SS & MS & $\%$ SS & SS & MS & $\%$ SS & SS & MS & $\%$ SS \\
\hline Environment (E) & 8 & 105.84 & $13.23^{* *}$ & 39.73 & 4404726.32 & $550590.79 * *$ & 57.36 & 5443.76 & $680.47^{* *}$ & 45.47 \\
\hline Genotype (G) & 9 & 83.52 & $9.28^{* *}$ & 31.35 & 1650837.87 & $183426.43^{* *}$ & 21.50 & 3623.13 & $402.57^{* *}$ & 30.26 \\
\hline GxE & 72 & 77.04 & $1.07^{* *}$ & 28.92 & 1624195.44 & $22558.27^{* *}$ & 21.15 & 2905.92 & $40.36^{* *}$ & 24.27 \\
\hline Mean & & \multicolumn{3}{|c|}{1.02} & \multicolumn{3}{|c|}{125.18} & \multicolumn{3}{|c|}{11.82} \\
\hline CV (\%) & & \multicolumn{3}{|c|}{43.4} & \multicolumn{3}{|c|}{56.9} & \multicolumn{3}{|c|}{29.66} \\
\hline
\end{tabular}

${ }^{*}$ and ${ }^{* *}$ significant differences at $5 \%$ and $1 \%$ probability, respectively. D.f: degrees of freedom, SS: sum of squares, MS: mean square, \%SS: percentage of the sum of squares, CV: coefficient of variation. 
AND AWF, respectively. Parga et al. (2005) stated that AMMI normally explains more variation with two or three principal components than that explained by analysis of variance in its corresponding source of variation. Sánchez et al. (2015) found that only two components explained $100 \%$ of the existing variation, with the tomato experimental hybrid $\mathrm{O} 3 \times \mathrm{R} 1$ being the best in terms of quality and yield. The evaluation environments were very different in their discrimination of genetic materials.

Table 4 summarizes the variables average production per plant $(\mathrm{kg} / \mathrm{pl})$, number of average fruits per plant and average weight of the fruit (g) for each genotype in each environment and the values of the coordinates of the main components for genotypes and environments. Likewise, figures 1,2 and 3 show the graphic representation of said variables.

As can be seen in table 4, the genotypes that showed higher production per plant through the environments were Sweet Million (control), followed by the genotypes IAC391, IAC1688, IAC1621 and IAC426, whose values ranged between 1.14 and $2.07 \mathrm{~kg} / \mathrm{pl}$ and, in turn, presented the highest absolute values of PC1, except for IAC1688, indicating the greatest interactions and, therefore, the best in favorable environments. In contrast, the genotypes IAC445, LA2076 and IAC412 obtained medium and low production values per plant (between $1.07 \mathrm{~kg} / \mathrm{pl}$ and 0.4 $\mathrm{kg} / \mathrm{pl}$ ) and presented the lowest absolute values of PC1, indicating small interactions and, therefore, the most stable genotypes across the environments.

The environments that contributed most to the genotype-environment interaction were T180K and T120K, which presented the highest absolute values in PC1, 0.5 and 0.56 , respectively. T180K contributed the most to the increased production per plant, with an average value of $1.89 \mathrm{~kg} / \mathrm{pl}$. The rest of the environments, with absolute values of PC1 close to zero, contributed little to the interaction. T0K (0.04) and MOK had low values because they were controlled artificial environments (zero potassium levels) (Tab. 4). Potassium has a significant effect on the quantity and quality of tomato yields because of its vital roles in photosynthesis, favoring high energy status and appropriate nutrient translocation and water uptake in

Table 4. Means and values of the coordinates of the principal components for genotypes and environments for cherry tomato production characteristics.

\begin{tabular}{|c|c|c|c|c|c|c|c|c|c|}
\hline Genotype & $\begin{array}{c}\text { Production per } \\
\text { plant (kg/pl) }\end{array}$ & PC1 & PC2 & $\begin{array}{c}\text { Number of fruits } \\
\text { per plant }\end{array}$ & PC1 & PC2 & $\begin{array}{c}\text { Average weight of } \\
\text { the fruit }(\mathrm{g})\end{array}$ & PC1 & PC2 \\
\hline IAC1621 (1)* & 1.39 & 1.14 & 1.00 & 162.58 & 77.89 & -2.14 & 10.92 & -4.5 & - \\
\hline IAC1624 (2) & 0.90 & - & 0.13 & 89.12 & -91.05 & -77.13 & 15.10 & 12.2 & -2.8 \\
\hline IAC1688 (3) & 1.41 & 0.57 & 0.39 & 242.87 & 280.3 & -88.34 & 8.07 & - & 0.7 \\
\hline IAC391 (4) & 1.44 & 1.14 & - & 117.9 & -23.52 & -39.46 & 16.27 & 2.98 & - \\
\hline IAC412 (5) & 0.40 & - & - & 32.79 & - & -75.73 & 14.63 & - & 0.82 \\
\hline IAC426 (6) & 1.14 & - & 0.04 & 177.61 & -75.08 & 167.88 & 9.99 & 5.05 & 8.31 \\
\hline IAC445 (7) & 0.81 & - & - & 93.83 & -63.93 & - & 11.96 & - & - \\
\hline LA2076 (8) & 1.07 & - & - & 128.92 & - & 36.90 & 9.84 & - & 0.6 \\
\hline LA2692 (9) & 0.64 & - & 0.42 & 166.19 & 53.69 & 214.36 & 7.20 & 1.92 & 0.54 \\
\hline Control (10) & 2.07 & 1.69 & - & 236.03 & 137.09 & -6.15 & 9.68 & - & 1.67 \\
\hline TOK & 1.61 & 0.04 & -0.09 & 251.29 & -0.05 & 0.72 & 7.26 & -0.27 & 0.02 \\
\hline T60K & 1.43 & 0.25 & -0.59 & 211.47 & 0.24 & -0.52 & 7.14 & -0.31 & 0.35 \\
\hline T120K & 1.61 & 0.56 & 0.61 & 254.98 & 0.69 & -0.13 & 7.22 & -0.47 & 0.05 \\
\hline T180K & 1.89 & 0.5 & -0.23 & 295.69 & 0.37 & 0.38 & 7.63 & -0.32 & -0.1 \\
\hline MOK & 1.00 & -0.22 & 0.28 & 79.36 & -0.18 & -0.06 & 14.50 & 0.28 & -0.16 \\
\hline M60K & 0.60 & -0.27 & 0.28 & 46.58 & -0.25 & -0.13 & 15.27 & 0.32 & -0.44 \\
\hline M120K & 0.76 & -0.39 & 0.06 & 58.29 & -0.35 & -0.01 & 15.11 & 0.22 & -0.37 \\
\hline M180K & 0.60 & -0.18 & -0.12 & 47.36 & -0.27 & -0.11 & 14.94 & 0.03 & -0.06 \\
\hline PAL & 0.57 & -0.27 & -0.22 & 51.37 & -0.19 & -0.15 & 12.89 & 0.53 & 0.71 \\
\hline
\end{tabular}

${ }^{*}$ The numbers in parentheses correspond with the respective name of the genotype in the figures of the biplot. 
plants (Amjad et al., 2014; Zörb et al., 2014; Woldemariam et al., 2018), enzyme activation, cell turgor maintenance, and ion homeostasis (Marschner, 1995).

Similar environments for ranking the genotypes were 0K, 60K, 120K, M180K and PAL, which indicated that one of these environments can be discarded without losing precision in the results. On the other hand, the environments T60K, T120K and T180K had responses that indicated specific genotypes, such as IAC1621 (1) and IAC1688 (3), which expressed their maximum yield potential in environment T120K (120 $\mathrm{kg} \mathrm{ha}^{-1}$ of potassium on the Tesorito farm) (Fig. 1B), with values that nearly exceeded $100 \%$ of the average of each one in the environments. On the other hand, the control genotypes and IAC391 proved to be more specific in environment T180K, yielding a production of $3.70 \mathrm{~kg} / \mathrm{pl}$ and $2.92 \mathrm{~kg} / \mathrm{pl}$, respectively, while genotype IAC426 was more specific for environment M120K. The most stable genotypes across the environments, as the result of their proximity to the center of the figure, were IAC445, LA2076 and IAC412 (Fig. 1A). Woldemariam et al. (2018) assessed the effect of potassium levels $(0,50,100,150,200,250$, 300,350 and $400 \mathrm{~kg} \mathrm{~K}_{2} \mathrm{O} / \mathrm{ha}$ ) on tomato productivity and fruit quality. The results of this study revealed that potassium had a significant effect on all yield and quality parameters. Increases in tomato yield, growth and fruit quality, when evaluated with different doses of sources of $\mathrm{K}$ and in balance with other micronutrients, have also been reported by Khan et al. (2014), Armita et al. (2017), Hernández-Pérez et al. (2019) and Weinert et al. (2021).

The control genotypes, IAC1621, IAC391 and IAC1688 showed the highest yield potential (greater than $1.3 \mathrm{~kg} / \mathrm{pl}$ ) and a degree of association with the different environments (potassium levels) in the natural environment (Tesorito). The genotypes with a greater genotype-environment interaction and lower yield potential, that is, those most associated with unfavorable environments, were IAC445, LA2692 and IAC1624, with PC1 absolute values close to one. IAC445 was the most stable across the environments (Fig. 1A, Tab. 3). Zayed et al. (2005) stated that high and stable yields are the main objective of plant breeding programs. A genotype must show good performance in a wide range of environments to be widely accepted.

For the variable number of fruits per plant, the genotypes with the greatest interaction through the environments were LA2692 (9) and LA1688 (3). Genotype LA2692 had positive PC1 and PC2 values associated with environments T0K and T180K, presenting values of 400 and 457 fruits per plant, respectively (Tab. 4, Fig. 2B). LA1688 presented the highest PC1 positive value (280.3), associated with environment T120K, where the maximum potential reached 594 fruits per plant. In contrast, genotype IAC426 was shown to be specific for environment T0K and reported 455 fruits per plant in that environment (Fig. 2A). Genotypes IAC412 and IAC445 had negative PC1 and PC2 values that were associated with the negative environments, which could be defined as Montelindo and Palmira mega-environments (Tab. 4, Fig. 2B).

For the variable average fruit weight, genotypes IAC391, IAC1624, IAC412, IAC1621 and IAC445 exhibited the highest values, oscillating between 10.92 and $16.27 \mathrm{~g} /$ fruit and with the highest absolute values
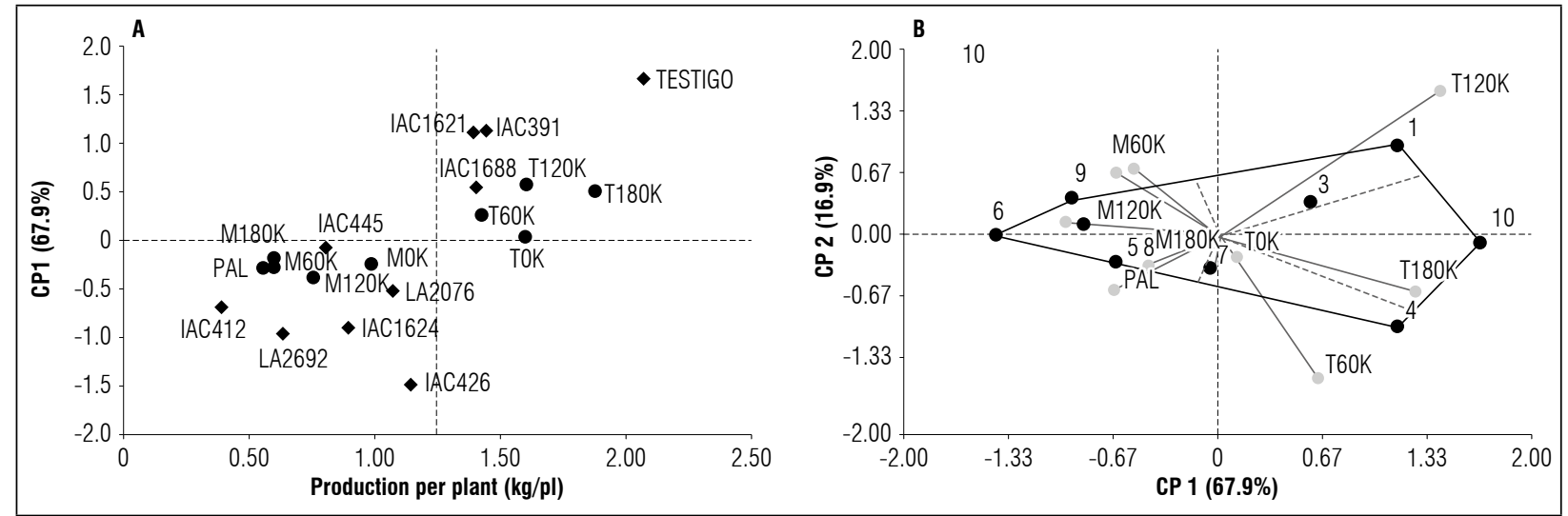

Figure 1. A and B, distribution of the ten tomato genotypes in the nine evaluation environments for the variable production per plant. 


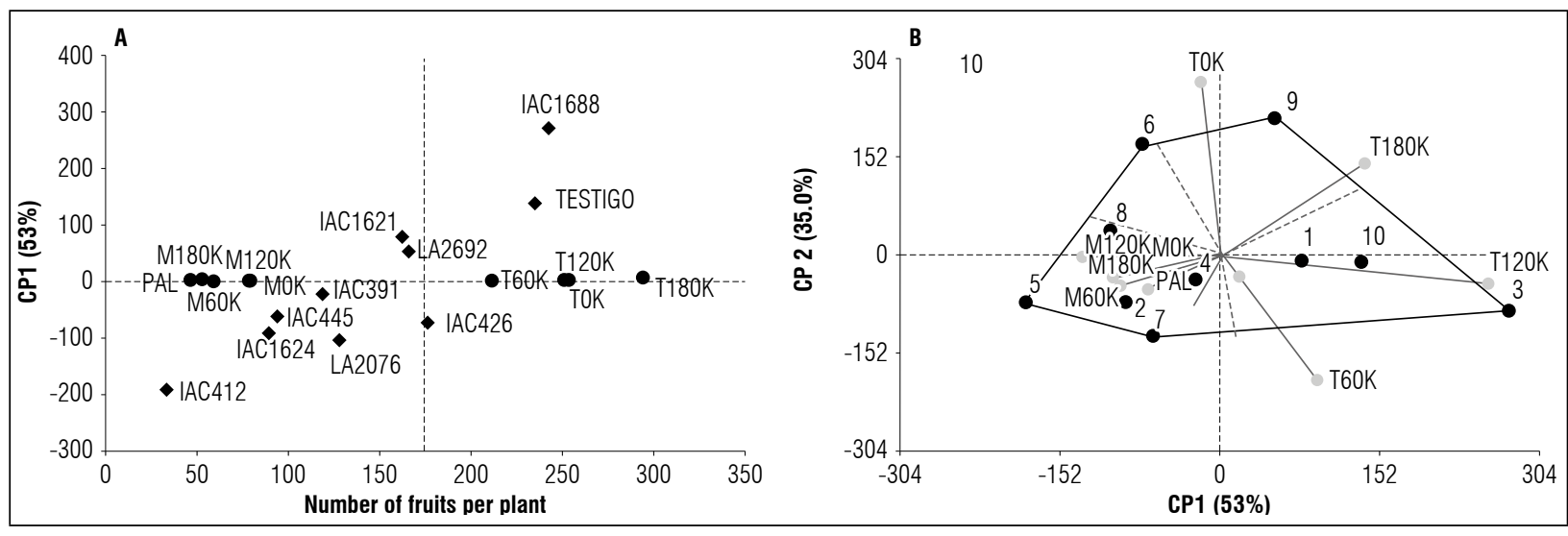

Figure 2. A and B, distribution of the ten tomato genotypes in the nine evaluation environments for the variable number of fruits per plant.

of PC1, indicating the greatest interactions and, therefore, the best in favorable environments (Tab. 4). Similar environments for ranking the genotypes were the Tesorito and Montelindo macro-environments with their respective artificial environments (0K, 60K, 120K and 180K). The Montelindo macroenvironment was more favorable for the expression of fruit weight and had PC1 and PC2 absolute values greater than zero. On the other hand, the Tesorito macro-environment showed the lowest fruit weight values and had negative PC1 values and PC2 values close to zero, except in environment T60K.

The results indicated that one of the artificial environments within the macro-environments could be discarded without losing precision in the results. In this case, the decision would be economical from the point of view of the cost of fertilization and the associated workforce using the benefit-cost ratio (Tab. 4, Fig. 3 A, B).

The environment Palmira (PAL) was the most interacting environment, presenting the highest absolute values in the two principal components (PC1 and PC2) and being the IAC426 genotype as the most specific, which had a fruit weight of $20.81 \mathrm{~g}$ in this environment.

The vertex genotypes with the highest interaction were IAC1624 (2) and IAC445 (7), specific to the Montelindo macro-environment; meanwhile, the control (10), along with genotype IAC1621 (1), had a stronger association with the Tesorito macro-environment. The most stable genotype across the environments with absolute values for PC1 and PC2 close to zero was LA2692, with an average fruit weight of 7.20 g (Tab. 4, Fig. 3 A, B).
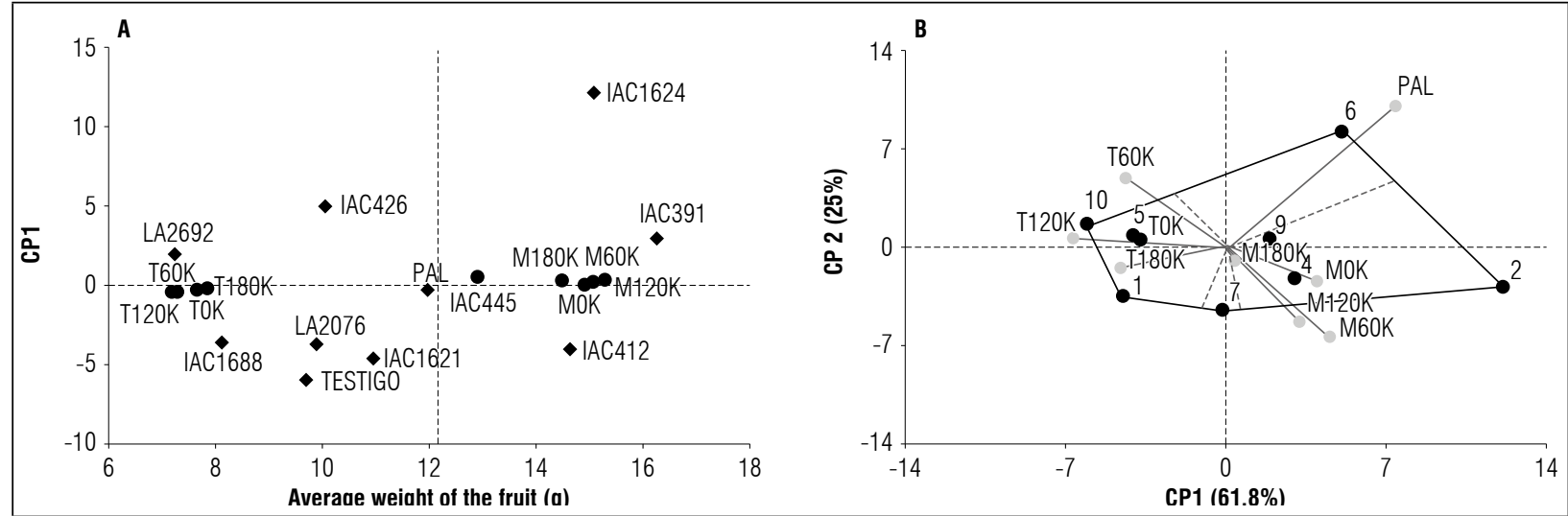

Figure 3. A and B, distribution of the ten tomato genotypes in the nine environments evaluated for the variable average fruit weight. 
The results identified groups of positively correlated environments, vectors in the same direction, and negatively correlated environments. This is important because it helps identify key environments and environments that better discriminate tomato genotypes. At the genotype level, this method identifies positively associated genotypes and groups of genotypes associated with specific environments.

\section{CONCLUSIONS}

The combined analysis of variance for the variables production per plant, number of fruits per plant and average fruit weight showed significant differences between the different genotypes, environments and genotype-environment interactions, indicating significant variations in the productive potential of the different genotypes and the differential response of this group of genotypes as the environment varies.

It is worth noting the need to identify and select specific genotypes for different environments to express their genetic potential in terms of economic importance for stable yields across localities for years. In this case, the environments T120K and T180K were optimal for the variables associated with production (PFT, NFT and AWF), with the most promising genotypes per environment being IAC1621, IAC426 and IAC1624 on the Farms Tesorito, Montelindo and CEUNP; respectively.

\section{ACKNOWLEDGMENTS}

The authors thank the Universidad Nacional de Colombia, Palmira, the Faculty of Agricultural Sciences, Graduate School, the Vice-Rector's Office for Research and Postgraduate Studies, and the doctorate Agricultural Sciences of the Universidad de Caldas for funding this study.

Conflict of interests: The manuscript was prepared and reviewed with the participation of the authors, who declare that there exists no conflict of interest that puts at risk the validity of the presented results.

\section{BIBLIOGRAPHIC REFERENCES}

Abdallah, R.A.B., S. Mokni-Tlili, A. NefzI, H.J. Khiareddine, and M. Daami-Remadi. 2016. Biocontrol of Fusarium wilt and growth promotion of tomato plants using endophytic bacteria isolated from Nicotiana glauca organs. Biol. Control 97, 80-88. Doi: 10.1016/j. biocontrol.2016.03.005

AGRONET. 2021. Crops - Tomato. In: http://www.agronet.gov.co/estadistica/Paginas/default.aspx; consulted: February, 2021.

Al-Aysh, F.M. 2014. Genotype-environment interaction and phenotypic stability for fruit yield and its productive components of tomato. J. Recent Adv. Agric. 2, 219-226.

Amjad, M., J. Akhtar, M. Anwar-Ui-Haq, S. Imran, and S. Jacobsen. 2014. Soil and foliar application of potassium enhances fruit yield and quality of tomato under salinity. Turk. J. Biol. 38, 208-218. Doi: 10.3906/ biy-1305-54

Armita, D., A.P. Rahayu, M.D. Maghfoer, and D.A.F. Fuadi. 2017. Effect of potassium fertilization on the yield and quality of two tomato varieties. Biosci. Res. 14(4), 1150-1155.

Balzarini, M.G. and J.A. Di Rienzo. 2003. Infogen: Software para análisis estadísticos de marcadores genéticos. Facultad de Ciencias Agropecuarias. Universidad Nacional de Córdoba. Cordoba, Argentina.

Casals, J., A. Rivera, J. Sabaté, R. Romero del Castillo, and J. Simó. 2018. Cherry and fresh market tomatoes: differences in chemical, morphological, and sensory traits and their implications for consumer acceptance. Agronomy (Switzerland) 9(9), 1-18. Doi: 10.3390/ agronomy 9010009

Crossa, J. 1990. Statistical analyses of multilocation trials. Adv. Agron. 44, 55-85. Doi: 10.1016/ S0065-2113(08)60818-4

Crossa, J., H.G. Gauch, and R.W. Zobel. 1990. Additive main effects and multiplicative interaction analysis of two international maize cultivar trials. Crop Sci. 30(3), 493-500. Doi: 10.2135/cropsci1990.0011183X0 03000030003x

Eberhart, S. and W. Russel. 1966. Stability parameters for comparing varieties. Crop Sci. 6, 36-40. Doi: 10.2135/ cropsci1966.0011183X000600010011x

FAO. 2021. FAOSTAT - Statis crops. In: www.faostat.org; consulted: April, 2021.

Flores-Hernández, L.A., R. Lobato Ortíz, J.J. García Zavala, J.D. Molina Galán, D.M. Sargerman Jarquín, and M.D. Velasco Alvarado. 2017. Parientes silvestres del tomate como fuente de germoplasma para el mejoramiento genético de la especie. Rev. Fitotec. Mex. 40(1), 83-91. Doi: 10.35196/rfm.2017.1.83-91

Hernández-Leal, E., R. Lobato-Ortiz, J.J. García-Zavala, A. Hernández-Bautista, D. Reyes-López, and O. Bonilla-Barrientos. 2019. Stability and breeding potential of tomato hybrids. Chil. J. Agric. Res. 79(2), 181-189. Doi: 10.4067/S0718-58392019000200181

Hernández-Pérez, O.I., L.A. Valdez-Aguilar, I. Alia-Tejacal, A.D. Cartmill, and D.L. Cartmill. 2019. Tomato fruit yield, quality, and nutrient status in response to 
potassium: calcium balance and electrical conductivity in the nutrient solution. J. Soil Sci. Plant Nutr. 20, 484-492. Doi: 10.1007/s42729-019-00133-9

Herrera, H., S.A. Hurtado, and A.N. Ceballos. 2015. Estudio técnico y económico del tomate tipo cereza élite (Solanum lycopersicum L. var. Cerasiforme) bajo condiciones semicontroladas. Rev. Colomb. Cienc. Hortic. 9(2), 290-300. Doi: 10.17584/rcch.2015v9i2.4185

Jaramillo, J., V.P. Rodríguez, M. Guzmán, M. Zapata, and T. Rengifo. 2007. Buenas prácticas agrícolas en la producción de tomate bajo condiciones protegidas. FAO, Gobernación de Antioquia, FAO-MANA, CORPOICA, Medellin, Colombia.

Khan, A.A., M. Sajid, A. Rab, S. Alam, and A. Bari. 2014. Effect of potassium sources on the growth, yield and fruit quality of tomato cultivars. Sarh. J. Agric. 30(4), 442-450.

Machado, J., L. Braz, and G. Grilli. 2003. Desempenho de produção de cultivares de tomateiro tipo Cereja em diferentes espaçamentos (CD). Hortic. Bras. 21(2), 356-356.

Mandal, A.R., B.K. Senapati, and T.K. Maity. 2000. Genotype-environment interaction, stability and adaptability of tomato (Lycopersicon esculentum Mill.). Veg. Sci. 27(2), 155-157.

Marschner, H. (ed.). 1995. Mineral nutrition of higher plants. $2^{\text {nd }}$ ed. Academic Press, New York, NY. Doi. 10.1016/B978-012473542-2/50010-9

Medina, C.I. and M. Lobo. 2001. Variabilidad morfológica en el tomate pajarito (Lycopersicon esculentum var. Cerasiforme), precursor del tomate cultivado. Corpoica Cienc. Tecnol. Agropecu. 3(2), 39-50. Doi: 10.21930/ rcta.vol3_num2_art:186

Mohamed, A.G., A.M. Ahmed, and R.M. Galal. 2013. Genotypic and phenotypic stability for new lines of tomato (Solanum lycopersicum L.). Assiut J. Agric. Sci. 44(2), 105-123.

Mohammadi, M., T. Hosseinpourt, M. Armion, H. Khanzadeh, and H. Ghojogh. 2016. Analysis of genotype, environment and genotype $\times$ environment interaction in bread wheat genotypes using GGE Biplot. Agri. Communi. 4(3), 1-8.

Nowosad, K., A. Liersch, W. Popławska, and J. Bocianowski. 2016. Genotype by environment interaction for seed yield in rapeseed (Brassica napus L.) using additive main effects and multiplicative interaction model. Euphytica 208, 187-194. Doi: 10.1007/s10681-015-1620-z

Panthee, D.R., C. Cao, S.J. Debenport, G.R. Rodriguez, J.A. Labate, L.D. Robertson, A.P. Breksa, E.V.D. Knaap, and B.B.M. Gardner. 2012. Magnitude of genotype $\mathrm{x}$ environment interactions affecting tomato fruit quality. HortScience 47(6), 721-726. Doi: 10.21273/ HORTSCI.47.6.721
Parga, T.V.M., V.V.M. Zamora, V.V.M. González, G.S.J. García, and G.E.E. Villavicencio. 2005. Interacción genotipo por ambiente en clones de papa bajo riego en el noreste de México. Agric. Téc. Méx. 31(1), 55-64.

Prasanna, H.C., T. Chaubey, R. Kumar, M. Rai, A. Verma, and S. Singh. 2007. Identification of stable variety for yield and quality attributes in tomato. Veg. Sci. 34, 131-134.

Sánchez, A., E.F. Borrego, V.V. Zamora, C.J. Sánchez, and R.F. Castillo. 2015. Estimación de la interacción genotipo-ambiente en tomate (Solanum lycopersicum L.) con el modelo AMMI. Rev. Mex. Cienc. Agríc. 6(4), 763778. Doi: 10.29312/remexca.v6i4.617

SAS Institute. 1992. User's guide v. 9.1. Cary, NC.

Savale, S.V. and A.I. Patel. 2017. Stability analysis for yield and quality attributes in tomato (Solanum lycopersicum L.). J. Pharmacogn. Phytochem. 6(6), 637-642.

Shankar, A., R.V.S.K. Reddy, P. Saidaiah, K. Uma Krishna, and K. Uma Jyothi. 2017. Study of stability analysis for yield and quality in tomato (Solanum lycopersicum L.) over the seasons. J. Entomol. Zool. Stud. 5(5), 505-509.

Srinivas, C., D. Nirmala, K. Narasimha Murthy, C.D. Mohan, T.R. Lakshmeesha, B. Singh, N.K. Kalagatur, S.R. Niranjana, A. Hashem, A.A. Alqarawi, B. Tabassum, E.F. Abd-Allah, S. Chandra Nayaka, and R.K. Srivastava. 2019. Fusarium oxysporum f. sp. lycopersici causal agent of vascular wilt disease of tomato: Biology to diversity - A review. Saudi J. Biol. Sci. 26(7), 1315-1324. Doi: 10.1016/j.sjbs.2019.06.002

Steel, R.G.D. and J.H. Torrie. 1997. Principles and procedures of statistics. A biometrical approach. $3^{\text {rd }}$ ed. McGraw-Hill, New York, NY.

Tonk, F.A., E. Ilker, and M. Tosun. 2011. Evaluation of genotype $\mathrm{x}$ environment interactions in maize hybrids using GGE biplot analysis. Crop. Breed. Appl. Biot. 11(1), 1-9. Doi: 10.1590/S1984-70332011000100001

Wardofa, G., D. Asnake, and H. Mohammed. 2019. GGE biplot analysis of genotype-by-environment interaction and grain yield stability of bread wheat genotypes in South Tigray, Ethiopia. J. Plant Breed. Genet. 7(2), 7585. Doi: $10.33687 /$ pbg.007.02.2846

Weinert, C.H., F. Sonntag, B. Egert, E. Pawelzik, S.E. Kulling, and I. Smit. 2021. The effect of potassium fertilization on the metabolite profile of tomato fruit (Solanum lycopersicum L.). Plant Physiol. Biochem. 159, 89-99. Doi: 10.1016/j.plaphy.2020.12.010

Woldemariam, S.H., S. Lal, D.Z. Zelelew, and M.T. Solomon. 2018. Effect of potassium levels on productivity and fruit quality of tomato (Lycopersicon esculentum L.). J. Agric. Stud. 6(1), 104. Doi: 10.5296/jas.v6i1.12262

Zakher, A.G., S.A.A. Abu El-kasem, and F.H. Ayoub. 2016. Assessment of the stability and adaptability of some newly promising tomato (Solanum lycopersicum L.) 
lines under different environmental conditions. J. Plant Prod. Mansoura Univ. 7(12), 1331-1337. Doi: 10.21608/jpp.2016.47031

Zayed, A.A., F.A. Helal, and S.T. Farag. 2005. The genetic performance of some continuously variable characteristics of pea under different locations. Ann. Agric. Sci. Moshtohor. 43(1), 337-346.

Zörb, C., M. Senbayram, and E. Peiter. 2014. Potassium in agriculture - status and perspectives. J. Plant Physiol. 171(9), 656-669. Doi: 10.1016/j.jplph.2013.08.008 